\title{
Plants used in folk cosmetics and hygiene in the Arribes del Duero Natural Park (western Spain)
}

\author{
José Antonio González, Mónica García-Barriuso, Rubén Ramírez-Rodríguez, \\ Sonia Bernardos \& Francisco Amich (*)
}

\begin{abstract}
González, J.A., García-Barriuso, M., Ramírez-Rodríguez, R., Bernardos, S. \& Amich, F. Plants used in folk cosmetics and hygiene in the Arribes del Duero Natural Park (western Spain). Lazaroa 33: 9-18 (2012).

In the present work we assess and document the ethnobotanical knowledge about cosmetic plants and plant species useful for personal and domestic hygiene in the Arribes del Duero Natural Park (provinces of Salamanca and Zamora, Spain). Field work was conducted between 2005 and 2009 by means semi-structured interviews and participant observation as well as transect walks in wild herbal plant collection areas, with 80 informants (mean age 72) in 18 localities. The informants, in particular the elderly women, are familiar with 32 useful plants distributed in 18 botanical families and know how to use them in a variety of ways. The most frequently used plants were Thymus mastichina (L.) L. and Quercus ilex subsp. ballota (Desf.) Samp. Different plant parts are used, but the branches are exploited more frequently. The uses documented are of great ecological value since the products obtained are less harmful to our health and the environment.
\end{abstract}

Keywords: plant resources, hygiene and cosmetics, traditional knowledge, Spain.

Resumen: González, J.A., García-Barriuso, M., Ramírez-Rodríguez, R., Bernardos, S. \& Amich, F. Plantas usadas en la cosmética tradicional y la higiene en el Parque Natural de Arribes del Duero (occidente español). Lazaroa 33: 9-18 (2012).

Se documenta y evalúa el conocimiento etnobotánico sobre plantas cosméticas y especies vegetales útiles en la higiene personal y doméstica en el territorio del Parque Natural de Arribes del Duero (Salamanca-Zamora, España). El trabajo de campo se ha llevado a cabo entre los años 2005 y 2009, mediante entrevistas semiestructuradas y observación directa de los participantes durante pequeñas salidas al campo en aquellas áreas de recolección de plantas silvestres, con 80 informantes (media de edad 72 años) en 18 localidades. Los informantes, en especial las mujeres de avanzada edad, poseen conocimiento de 32 plantas útiles, distribuidas en 18 familias botánicas, y de cómo manipularlas para obtener los productos deseados. Las especies usadas más frecuentemente son Thymus mastichina (L.) L. y Quercus ilex subsp. ballota (Desf.) Samp. La totalidad de las diferentes partes de las plantas son empleadas; no obstante, las ramas lo son con mayor frecuencia. Los usos tradicionales documentados tienen un gran valor ecológico, pues los productos obtenidos son menos perjudiciales para nuestra salud y el medio ambiente.

Palabras clave: recursos vegetales, higiene y cosmética, conocimiento tradicional, España.

\section{INTRODUCTION}

Daily work in rural settings generates dirtiness and people living in the rural environment are aware of the need for personal and domestic hygiene, the cleanliness of other areas used by them. Accordingly, they seek simple, close-by resources, especially those from the surrounding vegetation. Aromatic plants serve to freshen the skin and clothes; simple creams for the face and hands and hair lotions are made, and certain plants serve as raw materials for the elaboration of bleaching agents and soap for washing clothes. At present, traditional knowledge concerning home-made phytocosmetics is represented by both the remnants of an orally transmitted folk tradition and also by new forms of knowledge, sometimes coming from popular phytotherapeutic books and the mass media (PIERONI \& al., 2004). The use of certain natural products in cos-

* Duero-Douro Ethnobiological Resources Investigatión Group (GRIRED).University of Salamanca. E-37071 Salamanca, Spain. E-mail: ja.gonzalez@usal.es 
metic preparations is also based on their low toxicity and their active ingredients, responsible for both the effect and the benefits (ABURJAI \& NATSHEH, 2003).

As in other rural environments in the west of the Iberian Peninsula (e.g. CarvalHo, 2010; TEJERINA, 2010; Сово \& TiJera, 2011), the traditional knowledge (TK) of the people inhabiting the territory of the Arribes del Duero Natural Park (Salamanca-Zamora, Spain) -henceforth the "ARD"- can also be seen in the use of certain plant species to generate products for cleaning or aromatic use. Widely used in the recent past by most of the population, currently such species are less employed or have simply been lost from the memories of a few people of advanced age.

To preserve this TK, in recent years Spain has seen the introduction of norms regulating its natural resources and their use. The 42/2007 bill, providing for Spain's Natural Heritage and Biodiversity (ANONYMOUS, 2007), is the lynchpin of the creation of the Spanish Inventory of Natural Heritage and Biodiversity, in turn regulated by Royal Decree 556/2011 (ANonymous, 2011), which specifies its content, structure and functioning.

Following the aims and principles of this inventory, the aims of the present work were as follows: (i) to document and analyze the knowledge and traditional use of different plant species in the hygiene and cosmetic use of people from the ARD; (ii) to contribute to the dissemination of the results within the scientific community in order to open a door to research in other disciplines; and (iii) to contribute to the knowledge and conservational possibilities of plant biodiversity, bearing in mind that biological diversity is also related to the use and applications of natural resources.

\section{STUDY AREA}

The territory of the ARD forms the administrative border between Spain and Portugal along a stretch of some $120 \mathrm{~km}\left(40^{\circ} 50^{\prime}-41^{\circ} 35^{\prime} \mathrm{N}, 6^{\circ} 00^{\prime}\right.$ - $6^{\circ} 41^{\prime} \mathrm{W}$; Figure 1). In light of its extraordinary natural, landscape and faunistic value, it was declared a Natural Park in 2002, and is listed in the Sites of Community Importance proposed by Spain to become integrated within the European Natura 2000 network. It features a singular climatology on the Iberian Peninsula: a mild annual mean temperature $\left(11{ }^{\circ} \mathrm{C}\right.$ overall $)$, the almost complete absence of frost events along the year, and a mean precipitation of about $700 \mathrm{~mm} / \mathrm{yr}$ (CAlONGe-CANO 1990). From the geomorphological point of view, the ARD forms an extensive peneplain, whose most striking feature is the deep valley of the River Duero and its network (known as "arribes"). The considerable extent of this $\mathrm{Na}$ tural Park, together with its clear N-S orientation and the differences in altitude, explains why it has a very high plant diversity, characterized by an abundance of typically Mediterranean species (BERNARdos \& AMICH, 2000; NúÑEZ \& al., 2003; Амісн \& al., 2004). Distant from industrial areas, the territory is characterized by a strong demographic regression, which started half-way through the last century, with losses of almost $60 \%$ of the local population, a high ageing rate (almost $40 \%$ of people over 65 ), and a very low population density (8.6 inhabitants $/ \mathrm{km}^{2}$ ) (MoRALES \& CABALLERO, 2003). The economy is mainly based on the primary sector, livestock-raising being preponderant over crop-growing (CALABUIG, 2008).

\section{METHODOLOGY}

The incidence and socio-economic context of the use of plants for personal or domestic hygiene and cosmetics in general was studied as part of an ethnobotanical survey carried out in the ARD. Key informants, mostly elderly, with a sound TK of useful plants and who were born in the region and were long-time residents were interviewed. Information was obtained through 116 semistructured interviews of 80 people (44 men and 36 women; age range, 45-98 years; mean age, 72). They were from 18 localities shown in Figure 1: 6 in the province of Zamora (localities 1-6) and 12 in the province of Salamanca (localities 7-18). Interviews were conducted from 2005 to 2009. 


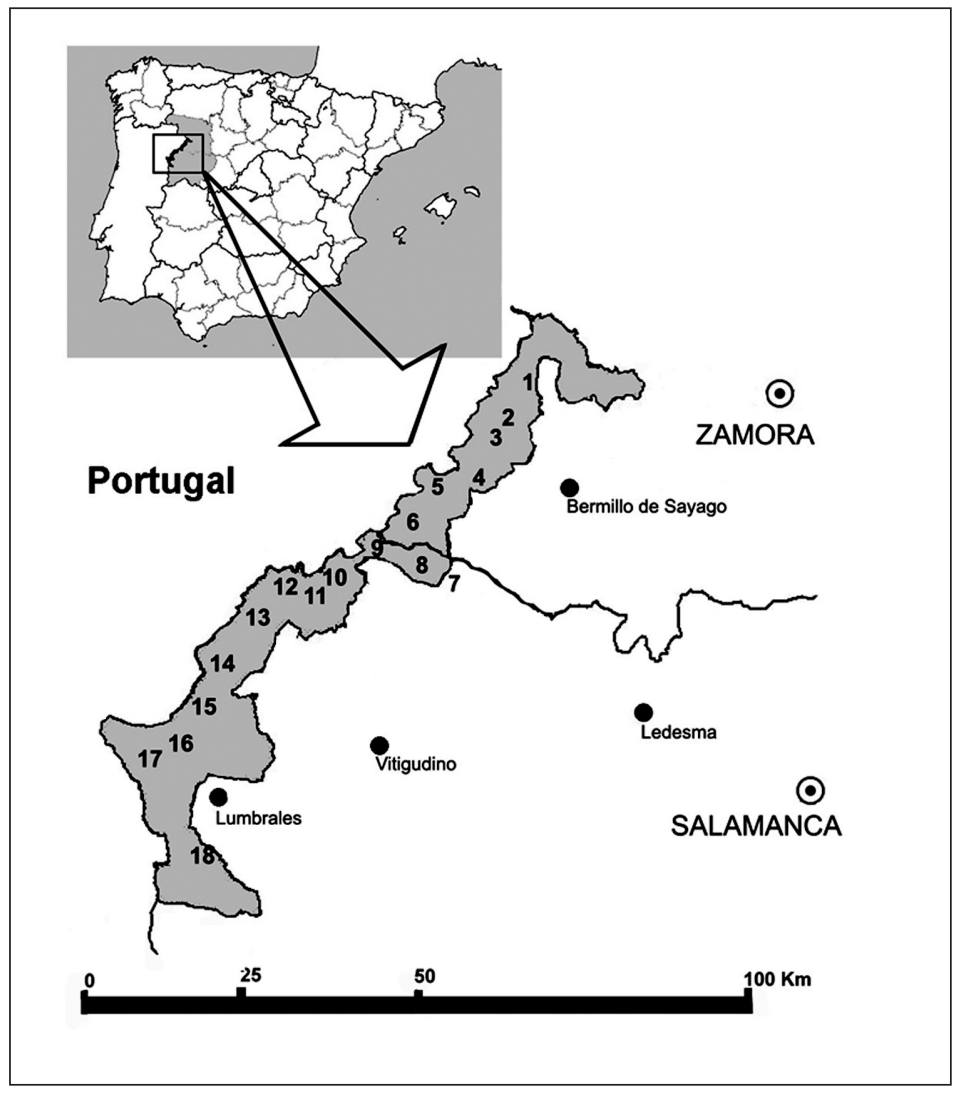

Figure 1.- Geographic location of the Arribes del Duero area and the villages where interviews were held. Province of Zamora: 1. Torregamones, 2. Badilla, 3. Fariza de Sayago, 4. Formariz, 5. Pinilla de Fermoselle, 6. Fermoselle. Province of Salamanca: 7. Almendra, 8. Trabanca, 9. Villarino de los Aires, 10. Pereña de la Ribera, 11. Masueco, 12. Aldeadávila de la Ribera, 13. Mieza, 14. Vilvestre, 15. Saucelle, 16. Hinojosa de Duero, 17. La Fregeneda, 18. San Felices de los Gallegos. The edge of the Arribes del Duero Natural Park is shaded.

Open questions were asked about the use of plants to gain insight into their past and present use.

The ethnobotanical data collected were grouped in the following use-categories of plants based on folk perceptions: (1) personal hygiene, (2) home-made cosmetics and perfumes, (3) domestic cleaning, (4) air-fresheners, and (5) as anti-moth agents.

In the analysis of the ethnobotanical catalogue, as well as the number of informants (frequency of citation, FC) we used the cultural importance (CI) index proposed by TARDÍO \& PARDO-DE-SANTAYANA (2008). This allows the relative importance of each plant species to be calculated. First, the use-reports (UR) of the species s are summed within a given use-category $\left(\mathrm{u}_{\mathrm{i}}\right)$ for all the infor- mants (from $i_{1}$ to $i_{N}$ ) and divided by the total number of informants $(\mathrm{N})$. Then, the previously calculated quotients for each use-category, from $\mathrm{u}_{1}$ to $\mathrm{u}_{\mathrm{NC}}$, are summed.

$$
\mathrm{CI}_{\mathrm{S}}=\sum_{u=u_{1}}^{u_{N C}} \sum_{i=i_{1}}^{i_{N}} U R_{u i} /_{N}
$$

Theoretically, this index varies between 0 and the total number of use-categories (NC), in our case 5 . The real value of $\mathrm{CI}$ is much lower than the theoretical minimum because it is difficult for a species to find a use in all categories and it is highly unlikely that all the informants would mention the use of such species in each category. 
To analyze how the informants' TK varied as regards socio-demographic characteristics, we performed an analysis of covariance (ANCOVA), taking "UR" as the variable to model (number of use-reports provided by each informant) and using the XLSTAT 2009 program. Likewise, as explanatory variables we took the two items of personal data requested: "age" and "gender" (qualitative values of $\mathrm{m}=$ male or $\mathrm{f}=$ female).

Regarding plant taxonomy and nomenclature we followed the "Flora iberica" (CASTROvieJO, 1986-2010) for the families included therein and the "Flora Europaea" (Tutin \& al., 1964-1993) for the remaining ones. Voucher specimens were deposited at SALA, the Herbarium of the University of Salamanca, Spain. In the case of some species for which no voucher was available, a digital photography number (PHO) is included.

\section{RESULTS AND DISCUSSION}

The inhabitants of the ARD use, or have used in the recent past, 32 vascular plants (included in 18 botanical families) for hygiene and cosmetic purposes. Table 1 lists the plant species cited by at least three informants and includes core botanical and ethnobotanical information about these plants.

The two botanical families best represented in the study are Lamiaceae, with 8 species (25\%), and Oleaceae, with 3 (9\%). Regarding the usecategories assigned to the plants surveyed, 37\% are used in the artisanal production of cosmetics and perfumes; $22 \%$ for personal hygiene, another $37 \%$ as air-fresheners, and 3 species (9\%) are used as anti-moth agents. The taxa obtained were mainly cultivated (53\%), and regarding the part of the plant used, branches (34\%) and flowers $(19 \%)$ were found to be the main organs used. At species level, the two most important taxa are Thymus mastichina $(\mathrm{CI}=1.10)$ and Quercus ilex subsp. ballota $(\mathrm{CI}=1.00)$.

The informants interviewed provided a total of 780 UR (average ca. 10 UR/informant). The results of the exploratory analysis conducted regarding the TK amassed by the different informants in terms of their characteristics show that only $45 \%$ of the variability of the TK can be explained in terms of age and gender $\left(\mathrm{R}^{2} \mathrm{adj} .=0.456\right)$. The remaining variability was due to certain effects (other explanatory variables) that were not, or could not, be measured during the study. We believe that some socio-economic effects might be involved, although in light of the results of the analysis of variance it may be concluded with a certain degree of confidence that the two explanatory variables do bring a significant amount of information to the model $\left(\mathrm{F}_{2,77}=34.140, \mathrm{P}<0.0001\right.$, confidence interval $=95 \%$ ). Table 2 gives details of the model . According to our data, women provided more information than men in this particular study.

\section{PERSONAL HIYGIENE}

The leaves and fresh flowers of the herbaceous plant known as "jabonera" (Saponaria officinalis) have been used as a substitute for soap for washing hands ("which stay soft and pliable"). In all of its parts, especially in the roots, this plant contains saponins; these are potentially toxic chemical compounds (PERIS \& StÜBING, 2006) that when used externally with water have a foam-forming and detergent action and serve for washing and degreasing. In the same sense, lemon juice (Citrus $x$ limon) is used to wash and degrease the hands, for example after having prepared olives for pickling (which leaves the hands very dirty).

Holm-oak (Quercus ilex subsp. ballota) or oak (Q. pyrenaica) ash together with hot water used to be used for washing the hair. These ashes, rich in potassium carbonate, have traditionally been used in personal hygiene for many years in Spain (BusCarons, 1986). When rinsing the hair a squirt of vinegar leaves it shiny.

Another important plant derivative is olive oil. Used in the kitchen, it is recycled for home-made soap for routine house cleaning, especially for washing clothes, although this soap is particularly important in personal hygiene.

Instead of toilet paper, the hairy leaves of Verbascum pulverulentum are used.

\section{HoME-MADE COSMETICS AND PERFUMES}

To soften the face, in the recent past decoctions were made with mallow flowers (Malva sylves- 


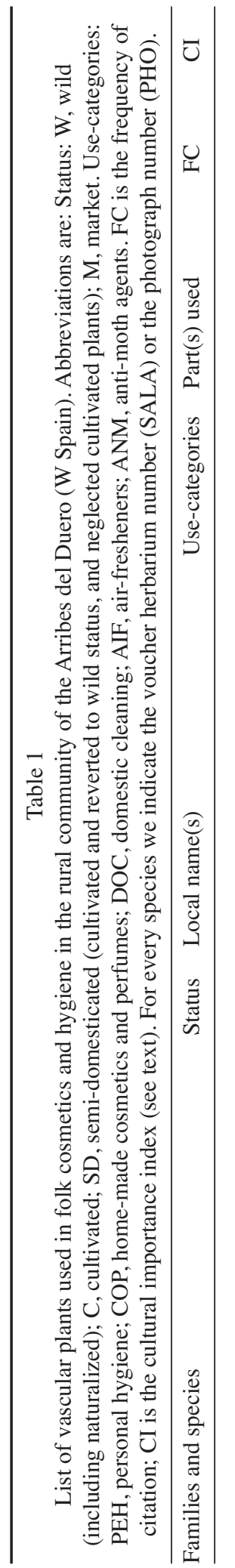

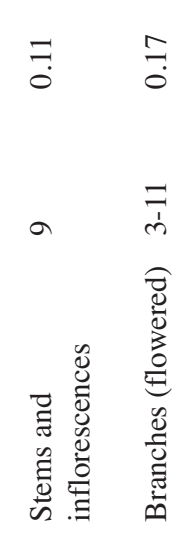

$$
\stackrel{2}{8}
$$$$
\stackrel{ \pm}{\circ}
$$

용

옹ํㅕㅇ<smiles>CCCCC</smiles>

$=$

声

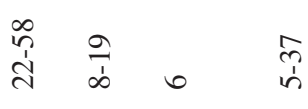

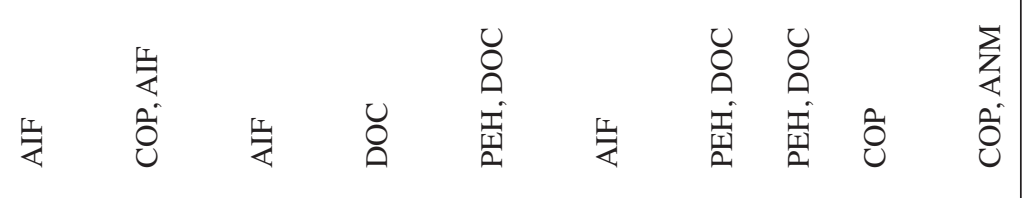
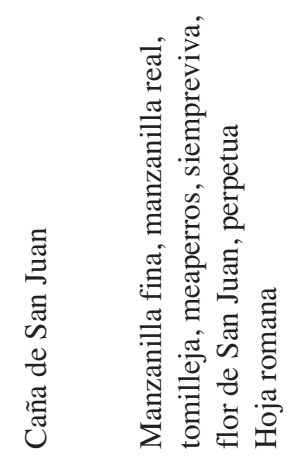

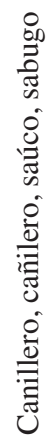

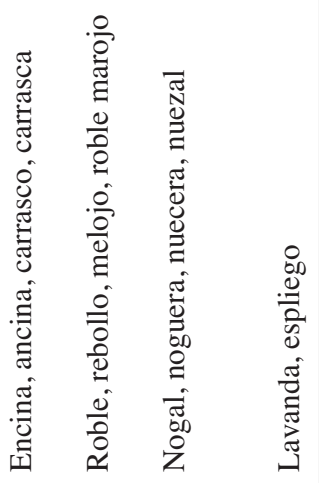

$3 \quad 3 \quad 3$

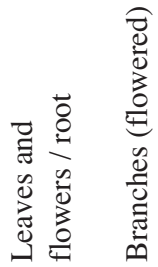

先 专

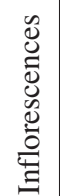

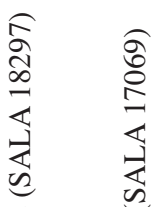

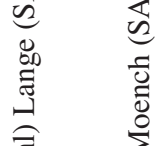

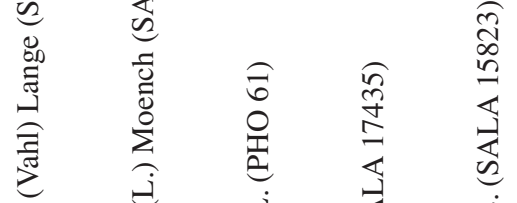

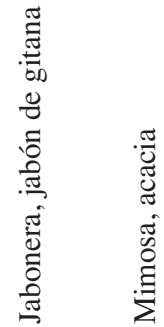

$3 \quad 3$ i

i

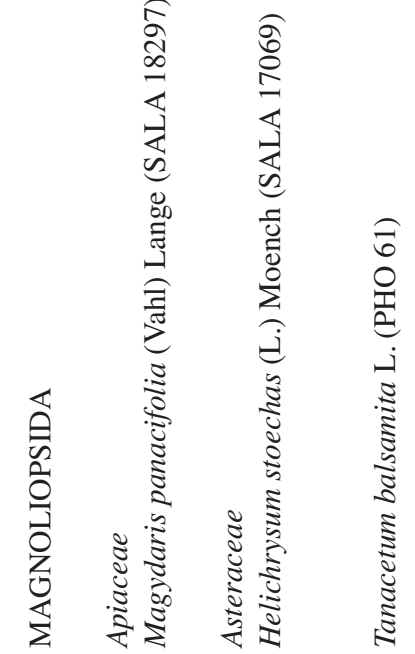

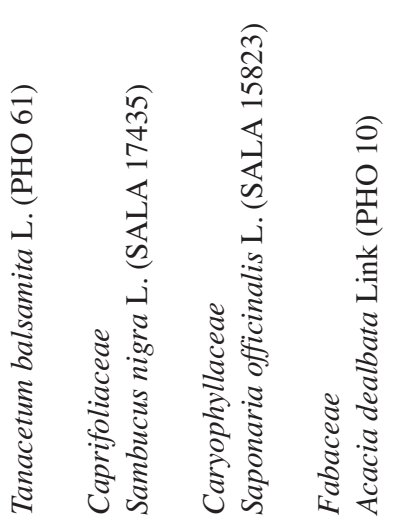

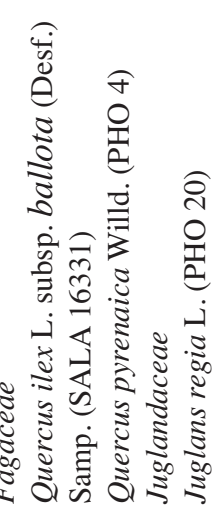



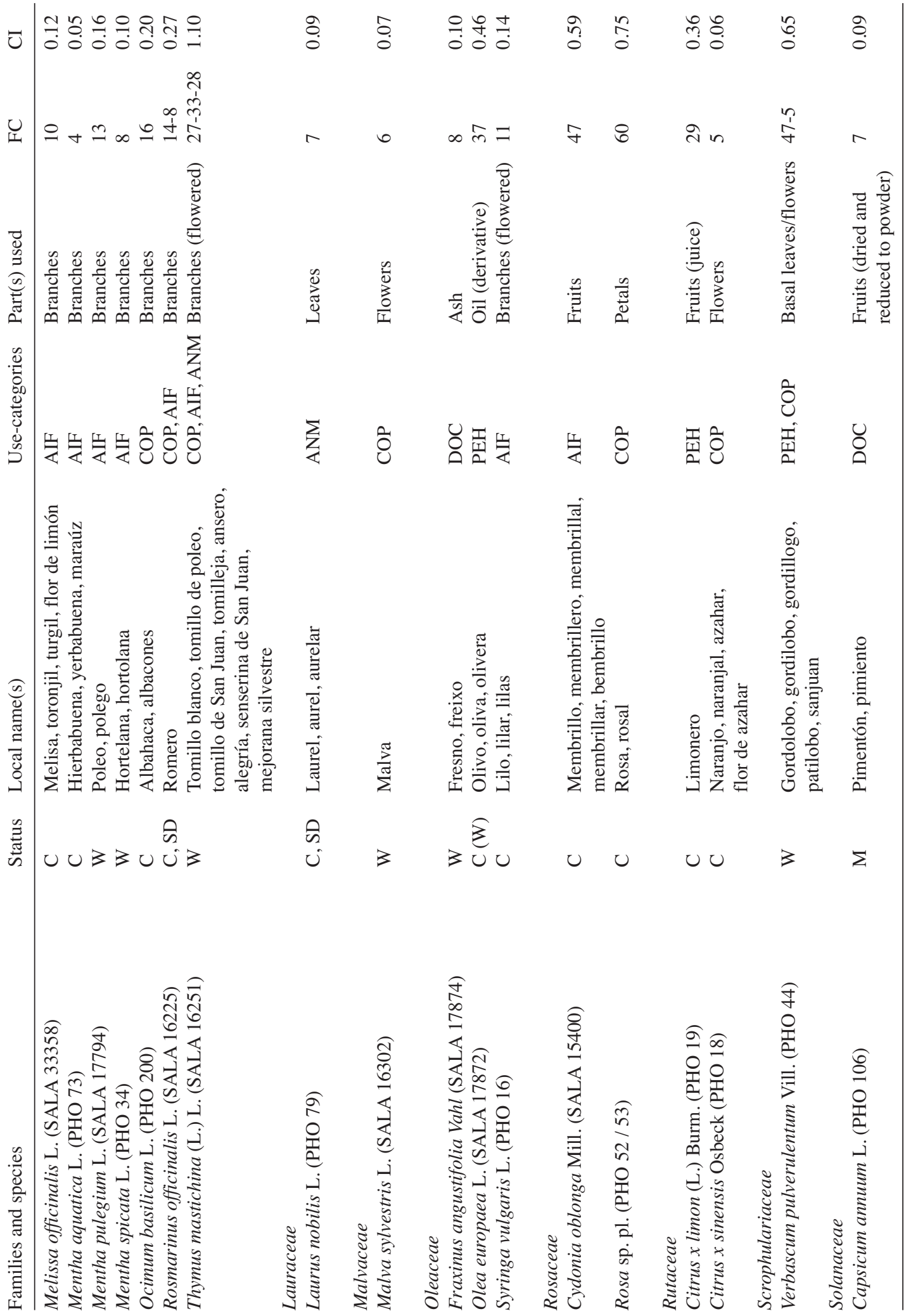


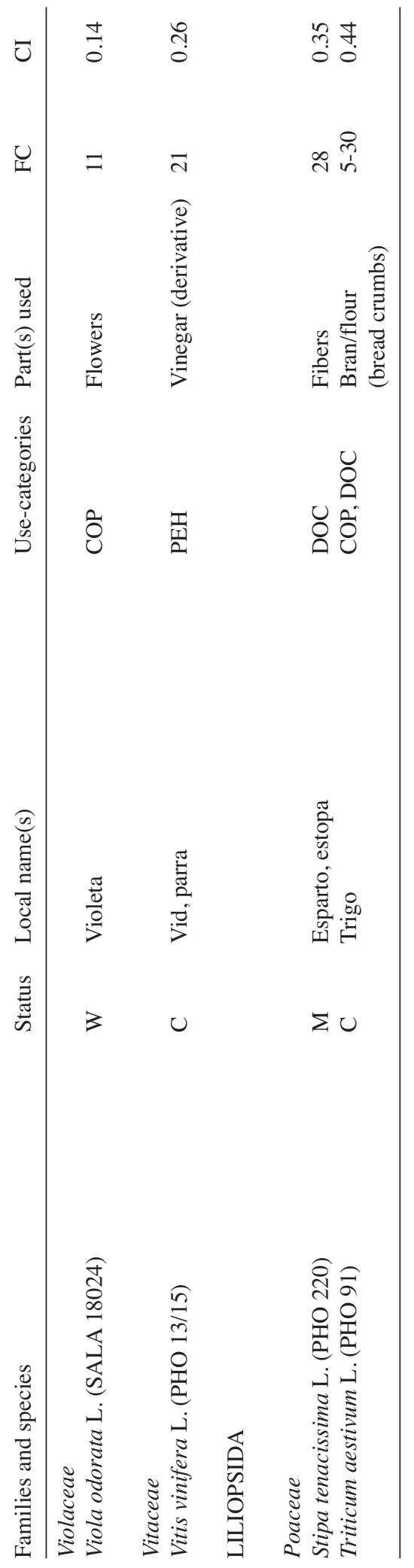


Table 2

ANCOVA results for the traditional knowledge and model parameters.

\begin{tabular}{lllll}
\hline Parameter & Value & SD & Student's t & Pr $>$ t \\
\hline Intercept & -8.828 & 4.224 & -2.090 & 0.040 \\
Age & 0.315 & 0.058 & 5.462 & $<0.0001$ \\
Gender - m & -7.209 & 1.173 & -6.146 & $<0.0001$ \\
Gender - f & 0.000 & 0.000 & - & - \\
\hline
\end{tabular}

tris), rose petals (Rosa sp. pl.) or wheat bran (Triticum aestivum). The women used to wash their faces daily with the resulting solution.

Regarding hair tonics, some plants have been used to obtain lotions for purposes other than mere washing. We documented three traditional plant remedies against baldness (GONZÁLEZ \& al., 2010), although it should be noted that they are also used to "lighten the hair"; that is, discolour it. Some people suffering from a progressive darkening of the hair, especially in the case of blonde women, would use the flowering branches of $\mathrm{He}$ lichrysum stoechas to wash their hair or used to cook the flower of Verbascum pulverulentum and use the resulting solution. Regarding grey hair, people would apply decoctions made from green walnuts (the immature fruit of Juglans regia). This stains the hair brown.

The perfumes traditionally used by the informants in the ARD were made at home, mainly through the maceration of braches or flowers in water and/or alcohol. Used individually or mixed, the six species documented in this work are rosemary (Rosmarinus officinalis), thyme (Thymus mastichina), rose bush, lavender (Lavandula angustifolia), and violet (Viola odorata, although Viola canina $\mathrm{L}$. also present in the territory, may be used), and orange (Citrus $x$ sinensis).

Women used to use bunches of basil (Ocimum basilicum) to adorn their lapels or would place them in the folds of their blouses on feast days.

\section{DOMESTIC CLEANING}

Not too long ago, in the ARD the inhabitants used to use a bleaching agent made from the combustion of the wood burnt at home; this was used as a household cleaner and for whitening sheets and clothes. The dirty linen was placed in a cauldron; a cloth was placed on top and on this was placed a fair amount of holm-oak or oak ash. Then, boiling water was poured over the ash and the cloth. This whitened and disinfected the clothes. After finishing the whitening, the clothes were rinsed and the spare dirty water was then used to clean the floor, which came up nicely after a rinsing with clean water. The potash of the ash acted as a salt-laden whitener, with the effects of a gentle diluted bleaching agent, and the clothes were disinfected by the simple act subjecting them to boiling water.

The ash from the slow combustion of wood from ash trees (Fraxinus angustifolia) was highly appreciated for whitening the wash and hanks of linen. This ash used to be boiled in iron pots; the clothes or hanks of linen were submerged in the boiling liquid and then left to dry in the sun.

To clean cauldrons, plates and other household goods, two of the plant resources mentioned above were used: the ash (mixed with water) from certain trees, mainly oak, and the roots of Saponaria officinalis. However, in this context another two traditional uses are important: dried and ground "pimentón" -paprika (Capsicum annuum)was used as a dye and preservative in the manufacture of chorizo and similar sausage products, and together with coarse salt and very hot water it was used to clean copper cauldrons. Elder (Sambucus nigra) branches were chopped up and boiled in water and the resulting solution was used once a year to clean the vessels used for storing olives. This was achieved by rubbing the inside with scouring pads made of beaten esparto grass (Stipa tenacissima) from old ropes or in disuse and removed any bad smells and disinfected the vessels. Also, bread (from wheat flour) was used to clean gold (chains, pendants, necklaces) and the old copper utensils that even today are used as decorative elements in kitchens (pans in particular).

\section{AIR-FRESHENERS}

For fragrances, although also as ornaments, the inhabitants of the ARD use certain plants as "airfresheners". To perfume stored clothing in cupboards or trunks they place fresh quinces 
(Cydonia oblonga) or branches of rosemary among their clothes. To perfume the air, apart from their culinary use, they place bunches made of lemon balm (Melissa officinalis), a plant that many inhabitants cultivate in their gardens/orchards, or of Thymus mastichina. It is also common to find vases containing different species of mint (Mentha aquatica, M. pulegium, M. spicata) or flowering branches of Helichrysum stoechas, which emits an agreeable odour of liquorice, or of trees such as Syringa vulgaris or Acacia dealbata, which as well as giving off a pleasant aroma are decorative owing to their vivid colouring.

In some villages of the ARD, in particular Villarino de los Aires (Salamanca), the inhabitants collect canes ("cañas de San Juan": Magydaris panacifolia) once a year for their pleasant smell (with an odour of cumaru, Dipteryx odorata (Aubl.) Willd., Fabaceae). With these canes, they make bunches, placed in vases, and sometimes make small bunches for use in cars. Four informants recall having placed a leaf of Tanacetum balsamita between the pages of their schoolbooks in their childhood.

\section{ANTI-MOTH AGENTS}

In a previous work (GoNZÁLEZ \& al., 2011) we reported data concerning certain plant species used as insect-repellents and/or insecticides in the struggle against disease-vectoring species: in particular mosquitoes and flies. Here we wish to include the insecticide plants used to prevent the proliferation of moths in stored clothes.

Tineid moths (Lepidoptera: Tineidae), commonly known as "clothes moths", inhabit human dwellings and storage areas and their caterpillars are considered a serious pest, since they derive nourishment from clothing, in particular wool, although also many other natural fibres. Control measures for the most common species, Tineola bisselliella Hummel 1823, known as the "common clothes moth" and the only species of its genus present in Europe (GAEDIKE, 2011), and Tinea pellionella L. 1758, the "case-bearing clothes moth", include physical measures such as dry-cleaning, but also solutions based on chemical methods that elicit problems of public health.
Because it is highly flammable, toxic and carcinogenic (IARC, 2002), naphthalene was replaced by 1,4-dichlorobenzene in mothball production; even then, mothballs should never be stored in places accessible to children or pets. Also, some of the chemical components used (permethrin, deltamethrin, etc.) are persistent in the ecosystem and toxic to humans and domestic animals (e.g. DoI \& al., 2006; LinNETT, 2008).

As a remedy for the protection of stored clothing in cupboards and trunks, commercial "bolas de alcanfor" (mothballs) are still used with a certain frequency in the ARD. However, as a natural method of prevention against moths -alternative to mothballs and insecticides-, the use of lavender inflorescences is a very common practice. Many people grow this aromatic plant in their gardens as an ornamental plant and then collect its inflorescences, dry them, and place them in small cloth bags to be hung in cupboards or trunks.

Laurel (Laurus nobilis) leaves are also used as an anti-moth agent, placed especially among stored blankets and winter clothing, and older women still place a bunch confected with the flowered branches of Thymus mastichina in their cupboards.

\section{CONCLUSIONS}

In all the uses documented, it may be seen that there is a noteworthy ecological value of the plants described, since on one hand the inhabitants recycle what in principle is a residue to be disposed of and, on the other, the home-made product obtained is less harmful or contaminating for the environment than many commercial products (detergents, degreasers, ammonia, etc.). Moreover, these plant resources are useful for airfreshening, with almost the same efficiency as modern chemical substances, and are reusable and do not generate health problems.

\section{ACKNOWLEDGEMENTS}

We would like to thank our informants for their time and effort to preserve traditional knowledge. 


\section{REFERENCES}

Aburjai, T. \& Natsheh, F.M. - 2003 - Plants used in cosmetics - Phytother. Res. 17(9): 987-1000.

Amich, F., Bernardos, S., Aguiar, C., Fernández-Diez, J. \& Crespí, A. -2004- Taxonomic composition and ecological characteristics of the endemic flora of the lower Duero Basin (Iberian Peninsula) - Acta Bot. Gallica 151: 341-352.

Anonymous - 2007 - Ley 42/2007, de 13 de diciembre, del Patrimonio Natural y de la Biodiversidad - BOE 299: 51275-51327.

Anonymous -2011 - Real Decreto 556/2011, de 20 de abril, para el desarrollo del Inventario Español del Patrimonio Natural y la Biodiversidad - BOE 112: 47905 47932.

Bernardos, S. \& Amich, F. - 2001 - Novedades y comentarios para la Orquidoflora centro-occidental ibérica Lazaroa 21: 13-18.

Buscarons, F. - 1986- Algunas prácticas empíricas en la higiene y en la medicina - Rev. Real Acad. Med. Barcelona 1: 33-40.

Calabuig, E.L. (Coord.) -2008 - Arribes del Duero: Guía de la naturaleza - Edilesa. León.

Calonge-Cano, G. - 1990 - La excepcionalidad climática de los Arribes del Duero - Ería 21: 45-59.

Carvalho, A.M. - 2010 - Plantas y sabiduría popular del Parque Natural de Montesinho: un estudio etnobotánico en Portugal - CSIC. Madrid.

Castroviejo, S. \& al. (Coord.) -1986-2010 - Flora iberica. Plantas vasculares de la Península Ibérica e Islas Baleares. Vols. I-VIII, X, XII-XV, XVII-XVIII, XXI - Real Jardín Botánico-CSIC. Madrid.

Cobo, M.P. \& Tijera, R.E. - 2011 - Etnobotánica de Doñana - Mancomunidad de Desarrollo y Fomento del Aljarafe. Sevilla.

Doi, H., Kikuchi, H., Murai, H., Kawano, Y., Shigeto, H., Ohyagi, Y. \& Kira, J. -2006- Motor neuron disorder simulating ALS induced by chronic inhalation of pyrethroid insecticides - Neurology 67(10): 1894-1895.

Gaedike, R. - 2011 - Fauna Europaea: Tineidae - In: Karsholt, O. \& van Nieukerken, E.J. (Eds.). Fauna Europaea: Lepidoptera, Moths - Fauna Europaea version 2.4. http://www.faunaeur.org (accessed in January, 2012).

González, J.A., García-Barriuso, M. \& Amich, F. -2010Ethnobotanical study of medicinal plants traditionally used in the Arribes del Duero, western Spain - J. Ethnopharmacol. 131(2): 343-355.

González, J.A., García-Barriuso, M., Gordaliza, M. \& Amich, F. - 2011 - Traditional plant-based remedies to control insect vectors of disease in the Arribes del Duero (western Spain): An ethnobotanical study - J. Ethnopharmacol. 138(2): 595-601.

International Agency for Research on Cancer (IARC) 2002 - Naphthalene - In: Some traditional herbal medicines, some mycotoxins, naphthalene and styrene. Pp. 367-435. IARC Monographs on the Evaluation of Carcinogenic Risks to Humans, vol. 82 - IARC Press. Lyon.

Linnett, P.J. - 2008 - Permethrin toxicosis in cats - Australian Vet. J. 86(1-2): 32-35.

Morales, C.G. \& Caballero, P. - 2003 - Parque Natural de Arribes del Duero: Análisis demográfico - In: Servicio de Espacios Naturales de la Junta de Castilla y León (Eds.). Libro del Parque Natural de Arribes del Duero. Pp. 8-12. Junta de Castilla y León. Valladolid.

Núñez, M.A., Tamajón, R. \& Recio, I.M. -2003 - Distribución ecológica en función del $\mathrm{pH}$ de varias especies leñosas mediterráneas en Sierra Morena (España) - Lazaroa 24: 49-60.

Peris, J.B. \& Stübing, G. -2006- Plantas tóxicas de la provincia de Albacete - Inst. Est. Albacetenses "Don Juan Manuel". Albacete.

Pieroni, A., Quave, C.L., Villanelli, M.L., Mangino, P., Sabbatini, G., Santini, L., Boccetti, T., Profili, M., Ciccioli, T., Rampa, L.G., Antonini, G., Girolamini, C., Cecchi, M. \& Tomasi, M. -2004- Ethnopharmacognostic survey on the natural ingredients used in folk cosmetics, cosmeceuticals and remedies for healing skin diseases in the inland Marches, Central-Eastern Italy - J. Ethnopharmacol. 91(2-3): 331-344.

Tardío, J \& \& Pardo-de-Santayana, M. -2008 - Cultural Importance indices: A comparative analysis based on the useful wild plants of southern Cantabria (Northern Spain) - Econ. Bot. 62: 24-39.

Tejerina, A. - 2010 - Usos y saberes sobre las plantas de Monfragüe: Etnobotánica de la Comarca Natural - Itomonfragüe. Cáceres.

Tutin, T., Heywood, V., Burges, A., Valentine, D., Moore, D., Walters, M. \& Webb, D. (Eds.) - 1964-1993 - Flora Europaea, vols. 1-5 - Cambridge Univ. Press. Cambridge, $\mathrm{UK}$. 